\title{
Ekstraksi Beta Karoten Dari Buah Kelapa Sawit (Elaeis Guineensis) Dengan Dua Jenis Pelarut
}

\section{Extraction of Beta Carotene From Oil Palm Fruit (Elaeis Guineensis) With Two Solvents}

\author{
I Made Widiantara, Yulianti, dan Bayu Setiawan Basri \\ Program Studi Teknologi Hasil Pertanian, Universitas Gorontalo \\ Jl. Abd. Wahab, No. 247, Limboto, Gorontalo \\ madewidiantara1994@gmail.com
}

\begin{abstract}
Abstrak
Tujuan penelitian ini yaitu untuk mengetahui perbandingan volume heksana dan petroleum eter yang tepat untuk mengekstrak beta karoten dari buah kelapa sawit. Penelitian ini menggunakan rancangan acak lengkap dengan tiga perlakuan dan tiga kali ulangan, perlakuan ini dilakukan dengan membedakan jumlah dari dua pelarut yang digunakan. Hasil penelitian dapat disimpulkan bahwa total padatan tertinggi yaitu pada perlakuan pelarut campuran antara heksana $250 \mathrm{ml}$ : petroleum eter 250 ml dengan jumlah $96,28 \%$, rendemen tertinggi diperoleh pada campuran heksana $250 \mathrm{ml}$ : petroleum eter $250 \mathrm{ml}$ dengan jumlah $2,73 \%$, kandungan beta karoten tertinggi yaitu pada campuran heksana $125 \mathrm{ml}$ : petroleum eter $375 \mathrm{ml}$ dengan jumlah 0,71 ppm. Dan efektivitas pelarut heksana dan petroleum eter yang terbaik dalam melarutkan beta karoten adalah perlakuan ketiga dengan pencampuran heksana $125 \mathrm{ml}$ : petroleum eter $375 \mathrm{ml}$ menghasilkan 0,71 ppm kadar beta karoten.
\end{abstract}

Kata kunci : beta karoten; ekstraksi; heksana; petroleum eter

\begin{abstract}
The purpose of this study was to determine the appropriate volume ratio of hexane and petroleum ether to extract beta carotene from oil palm fruit. It applied completely randomized design with three treatments and three repetitions. The treatment was to differentiate number of two used solvents. Findings revealed that the highest solid was on mixed solvents between 250 $\mathrm{ml}$ hexane : petroleum eter by having the percentage of $96,28 \%$, the highest rendemen was mixed solvents between $250 \mathrm{ml}$ hexane : $250 \mathrm{ml}$ petroleum eter by having the percentage of $2,73 \%$, the highest beta carotene content was mixed solvents between $125 \mathrm{ml}$ hexane : $375 \mathrm{ml}$ petroleum eter for 0,71 $\mathrm{ppm}$, and the most effective solvent concentration in dissolving the beta carotene was the mixture of $125 \mathrm{ml}$ hexane : 375 petroleum eter which produced $0,71 \mathrm{ppm}$ beta carotene.
\end{abstract}

Keywords: beta carotene; extraction; hexane; petroleum ether

\section{PENDAHULUAN}

Produksi kelapa sawit merupakan bagian penting dari ekonomi Indonesia karena negara ini merupakan produsen dan konsumen sawit terbesar didunia. Indonesia memasok kurang lebih separuh pasokan sawit dunia. Luas kebun sawit 
di indonesia mencapai 6 juta hektar pada tahun 2015, Indonesia berencana membangun 4 juta hektar kebun untuk produksi bahan bakar bio yang bersumber dari minyak sawit (BPS, 2015).

Kelapa sawit yang masak memiliki ciri buah bewarna merah kekuningan. Warna merah buah kelapa sawit disebabkan oleh beta karoten yang terkandung didalamnya, beta karoten merupakan pro vitamin A yang sangat penting bagi manusia dan beta karoten merupakan antioksidan bagi minyak (Raharjo, 2004). Beta karoten adalah salah satu jenis karatenoid yang berfungsi sebagai prekursor vitamin A, pigmen esensial untuk kesehatan mata dan mecegah kebutaan. Beta karoten tergolong antioksidan yang baik untuk menghambat radikal bebas (Bonnie \& Choo, 1999). Beta karoten juga dapat digunakan sebagai pewarna makanan, namun dalam proses pemanfaatan buah sawit sebagai sumber beta karoten dan pewarna makanan belum optimal.

Beta karoten merupakan salah satu jenis karotenoid. Karotenoid bersifat tidak larut dalam air, metanol, etanol dingin, larut dengan baik dalam pelarutpelarut organik seperti karbon disulfida, benzena, kholoform, aseton, eter dan petroleum eter (Purnamasri et al, 2013). Beta-karoten merupakan senyawa non polar yang sangat larut baik dalam pelarut non polar seperti heksana (Gusti, 2012). Metode ekstraksi dengan menggunakan larutan cair biasa disebut juga ekstraksi pelarut (solvent extraction). Metode ini melibatkan pelarut dengan tujuan untuk memisahkan komponen yang diinginkan, dimana pelarut melarutkan sebagian bahan padatan sehingga bahan terlarut yang diinginkan dapat diperoleh.

Ekstraksi beta karoten pada kelapa sawit sebelumnya telah dilakukan oleh Supardan (2009) dengan mengekstraksi karatenoid dari minyak CPO sawit dengan menggunakan pelarut petroleum eter dan heksana dan pemurnian menggunakan bantuan ultrasonic. Sedangkan Tamara dan Purwanto (2013), mengekstraksi beta karoten dari minyak sawit mentah dengan pelarut isopropanol dimana diketahui bahwa isopropanol kurang selektif dalam menyerap beta karoten. Sedangkan pada penelitian ini proses ekstraksi akan dilakukan dengan menggunakan campuran pelarut heksana dan petroleum eter dengan teknik maserasi pada kulit kelapa sawit. Menurut Yulianti et al (2017), menyatakan bahwa penggunaan campuran antara heksana dan petroleum eter tingkat polaritasnya mendekati beta karoten dibandingkan pelarut tanpa campuran. Adapun tujuan dilakukannya penelitian ini yaitu untuk mengetahui perbandingan konsentrasi antara heksana dan petroleum eter yang tepat untuk mengesktrak beta karoten dari buah kelapa sawit.

\section{METODOLOGI}

Bahan yang digunakan yaitu buah kelapa sawit yang diperoleh dari perkebunan rakyat di Desa Panca Mukti Kabupaten Donggala Provinsi Sulawesi Tengah, maltodekstrin, heksana, petroleum eter dan almunium foil. Sedangkan alat yang digunakan antara lain panci, baskom, gelas kimia, kain saring, spatula, gelas ukur, pipet volume, gelas ukur, refrigerator, dan oven.

Metode yang digunakan pada penelitian ini yaitu rancangan acak lengkap dengan tiga perlakuan dan tiga kali ulangan yang dilanjutkan dengan uji lanjut duncan. Dengan parameter pengamatan terdiri dari total padatan, rendemen dan kandungan beta karoten prosedur buah sawit direbus selama 30 menit. Buah sawit yang telah direbus, dipisahkan antara biji dan daging. Daging buah kemudian 
ditambahkan pelarut sesuai perlakuan (A1 : Heksana $250 \mathrm{ml}$ : Petroleum eter 250 $\mathrm{ml}$, A2 : Heksana $375 \mathrm{ml}$ : Petroleum eter $175 \mathrm{ml}$, dan A3 : Heksana $125 \mathrm{ml}$ : Petroleum eter $375 \mathrm{ml}$ ) dan diamkan selama 1 jam. Campuran disaring dengan menggunakan kain saring, dan dilakukan penimbangan ampas, hasil dari penyaringan disimpan dalam refrigerator selama 48 jam. Setelah selesai dari refrigerator ekstrak kemudian dipisahkan dengan pelarutnya di timbang dan dikeringkan pada suhu $50^{\circ} \mathrm{C}$ selama 4 hari ( \pm 89 jam $)$. Sebelum dikeringkan ditambahkan bahan pengisi maltodekstrin sebanyak 10\% dari berat esktrak.

\section{HASIL DAN PEMBAHASAN}

\section{Total Padatan}

Pengeringan merupakan salah satu cara untuk menghilangkan atau mengeluarkan air pada bahan. Kecepatan proses pengeringan ditentukan oleh beberapa faktor diantaranya jenis bahan yang akan dikeringkan, suhu dan alat yang digunakan untuk mengeringkan. Jenis bahan yang dikeringkan tergantung dari bentuk, ukuran dan komposisi bahan tersebut. Bahan yang bersifat cair akan memerlukan waktu yang relatif lama untuk mendapatkan bahan yang benar-benar kering. Lama proses pengeringan tergantung pada bahan yang dikeringkan dan cara pemanasan yang digunakan (Rahmawan,2011).

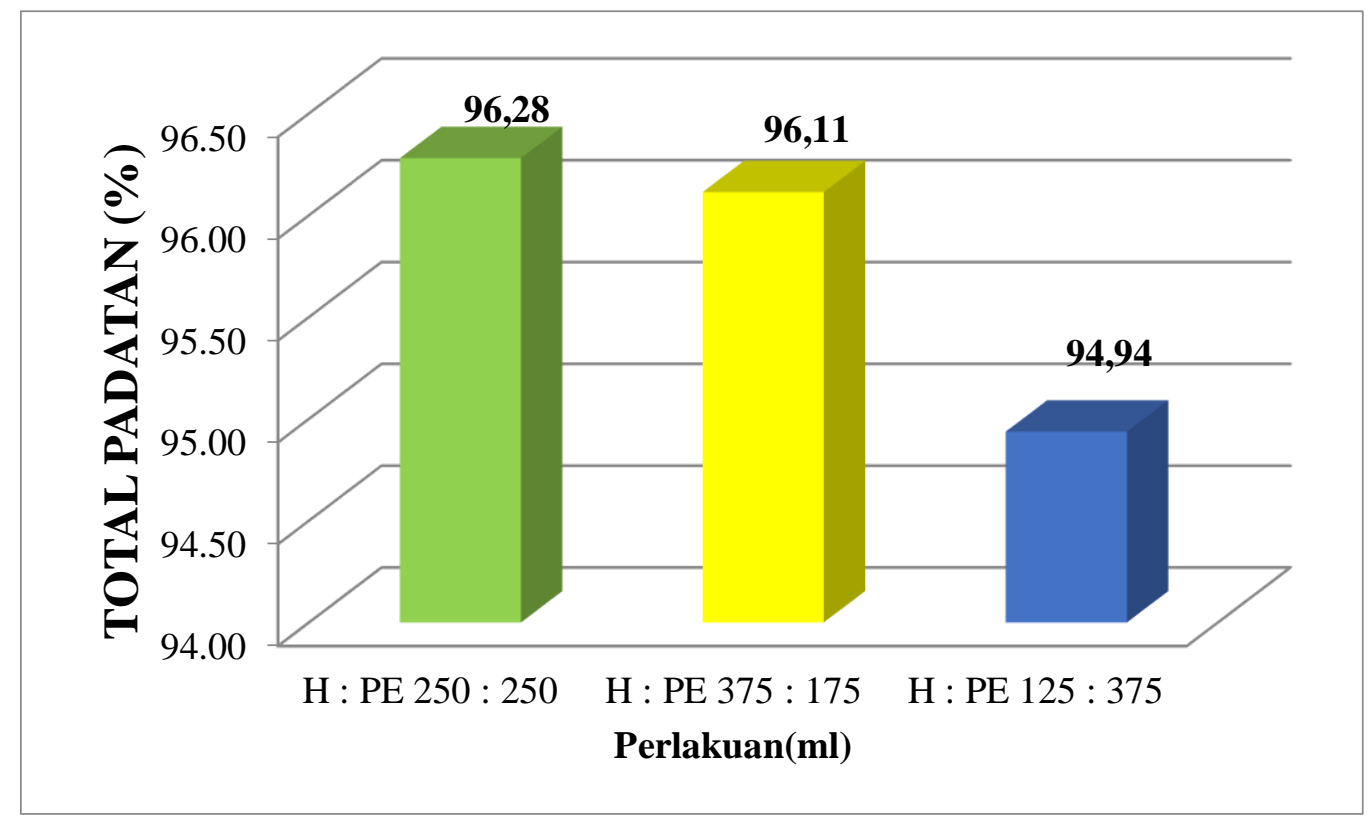

Gambar 1. Total Padatan Ekstrak Beta Keroten Buah Kelapa Sawit (H : Heksana; PE : Petroleum eter)

Gambar 1 menunjukkan nilai total padatan bubuk pewarna yang tertinggi yaitu pada perlakuan pertama dengan penggunaan pelarut heksana $250 \mathrm{ml}$ : petroleum eter $250 \mathrm{ml}$ yaitu 96,28\%, dan yang terendah pada perlakuan ketiga dengan campuran heksana $125 \mathrm{ml}$ : petroleum eter $375 \mathrm{ml}$ yaitu 94,94\%. Berdasarkan uji lanjut Duncan perbadingan volume pelarut yang dugunakan dalam mengekstrak beta karoten memberikan pengaruh yang berbeda dan berpengaruh terhadap total padatan yang dihasilkan. Total padatan yang terdapat pada sampel merupakan komponen-komponen yang ikut terekstrak dalam proses ekstraksi. Komponen yang terlarut yang memiliki tingkat kesesuaian polaritas terhadap 
pelarut, sehingga dalam proses ekstraksi komponen yang bersifat non polar akan ikut larut.

Perlakuan dengan pencampuran dua jenis pelarut yang berbeda menghasilkan tingkat kepolaran yang berbeda sehingga, jumlah komponen yang terekstrak berbeda. Komponen yang sesuai dengan tingkat kepolaran akan ikut terlarut baik itu komponen beta karoten maupun komponen lain yang bersifat non polar. Prinsip kelarutan adalah like dissolve like, yaitu pelarut polar akan melarutkan senyawa polar dan pelarut non polar akan melarutkan senyawa non polar (Kiswandono, 2011). Sesuai dengan prinsip ini kemungkinan ada senyawa lain yang bersifat nonpolar ikut terekstrak. Yulianti (2013) menyatakan bahwa pada proses ekstraksi beta karoten pada wortel, komponen-komponen yang ikut terekstrak seperti alfatokoferol, likopen dan senyawa non polar lainnya.

\section{Rendemen}

Rendemen akhir dari pewarna bubuk dari buah kelapa sawit dipengaruhi oleh banyaknya komponen yang terekstrak pada saat proses ekstraksi. Dimana keberhasilan proses ekstraksi sangat ditentukan oleh penggunaan pelarut. Kesesuaian pelarut dengan komponen yang akan diekstrak akan menghasilkan rendemen yang tinggi. Komponen yang bersifat polar akan larut pada pelarut polar, begitupun pada komponen nonpolar akan larut pada pelarut non polar.

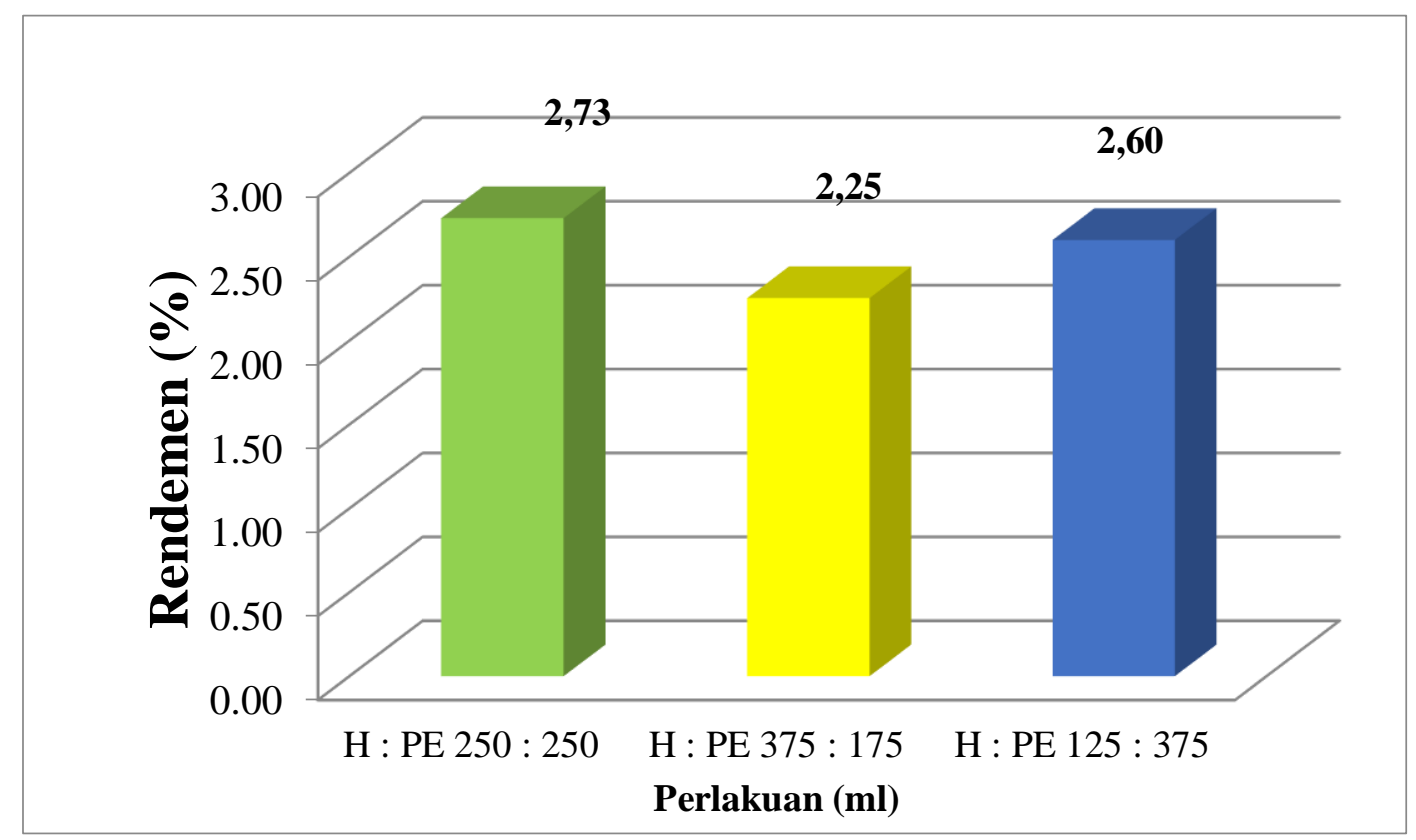

Gambar 2. Rendemen Ekstrak Beta Keroten Buah Kelapa Sawit (H : Heksana; PE : Petroleum eter)

Perlakuan jenis pelarut tidak berpengaruh nyata terhadap rendemen yang dihasilkan (Gambar 2). Banyaknya komponen yang terekstrak dipengaruhi oleh jenis pelarut yang digunakan dalam hal ini sifat polaritas pelarut dan komponen yang diekstrak harus sama, komponen yang bersifat polar akan terekstrak dengan pelarut yang bersifat polar, begitupun komponen yang bersifat non polar akan terekstrak dengan pelarut yang bersifat non polar. Hal ini sesuai dengan pernyataan Bennita (2008), bahwa prinsip ekstraksi adalah melarutkan senyawa polar dalam pelarut polar dan senyawa non polar dalam senyawa non polar. 


\section{Kandungan Beta Karoten}

Beta karoten merupakan senyawa organik yang banyak terdapat pada buah kelapa sawit. Adanya beta karoten pada buah kelapa sawit dapat dilihat dari warna yang bewarna kuning kemerahan. Semakin merah kelapa sawit maka semakin tinggi kadar beta karotennya. Beta karoten salah satu jenis karoten yang penting bagi tubuh yang dapat menanggulangi kebutaan dan mengurangi peluang terjadinya penyakit kanker dan tergolong antioksidan kuat. Minyak sawit berjumlah $1 \%$ terdiri dari karoten, tokoferol, sterol, alkohol, triterpane, fosfolipida. Karoten dikenal sebagai pigmen warna jingga, kandungan dalam minyak sawit mencapai 0,005$0,18 \%$, setiap satu ton minyak mengandung lebih 240 gram karoten (Fauzi, 2008). Minyak sawit mengandung beta kroten 31\% dari total karotenoid 4000-6000 ppm (Choo et al, 1996).

Beta karoten pada buah kelapa sawit dapat diekstrak dengan menggunakan pelarut yang bersifat non polar, karena beta karoten merupakan senyawa organik yang bersifat non polar. Beta karoten bersifat non polar karena pada gugusnya tidak memiliki gugus OH (hidroksil) (Lung dan Destiani, 2018). Pelarut yang sesuai untuk mengekstrak beta karoten yaitu heksana, petroleum eter, dan pelarut non polar lainya.

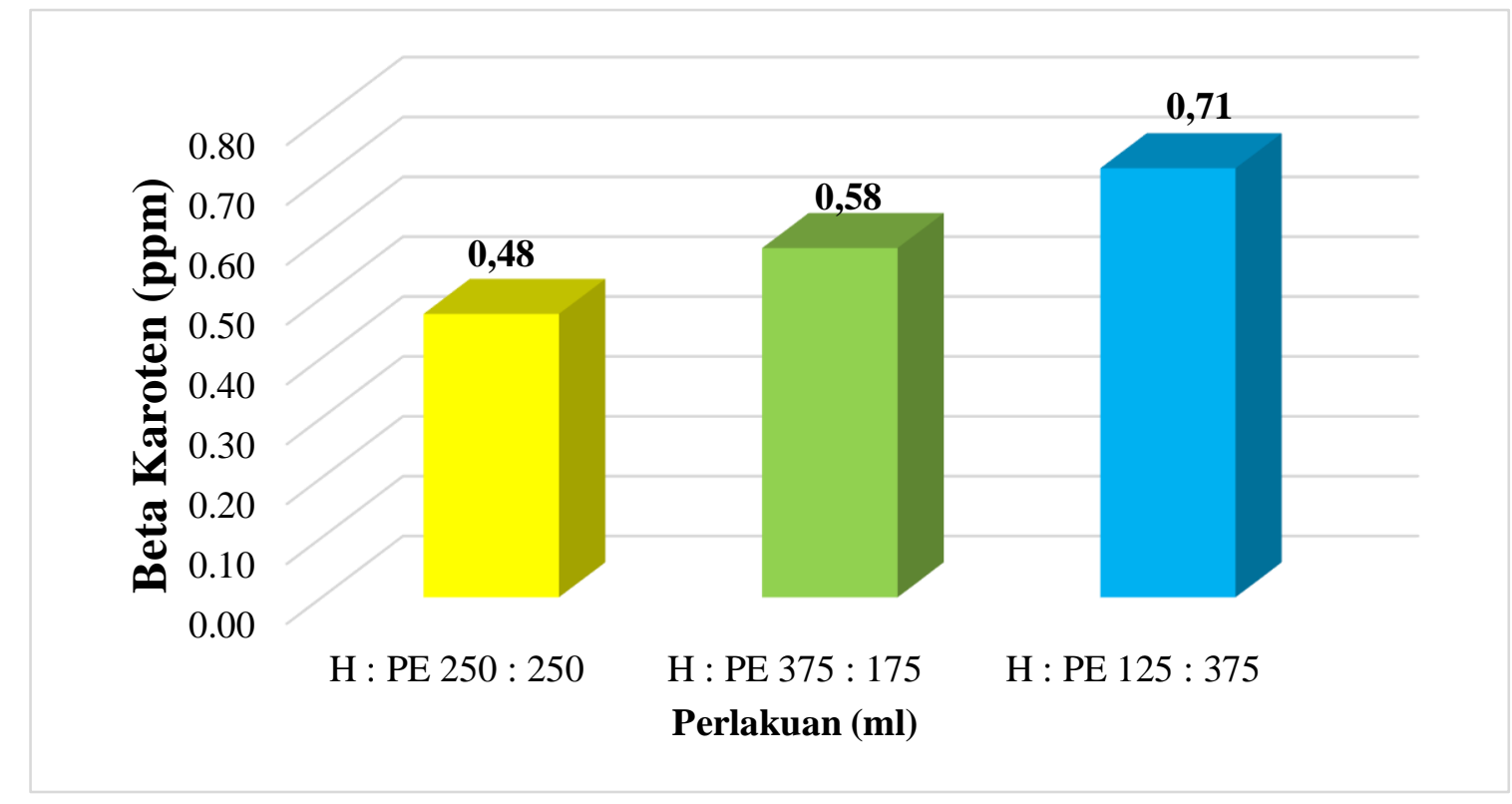

Gambar 3. Kandungan Beta karoten Buah Kelapa Sawit (H : Heksana; PE : Petroleum eter)

Kandungan beta karoten tertinggi pada perlakuan heksana $125 \mathrm{ml}$ dan petroleum eter $375 \mathrm{ml}$ sebesar 0,71 ppm. Hal ini menunjukkan bahwa penggunaan pelarut yang sama namun volume yang berbeda menghasilkan tingkat kepolaran yang berbeda. Berdasarkan uji lanjut Duncan perbedaan volume pelarut antara heksana dan petroleum eter memberikan pengaruh yang signifikan terhadap hasil ekstrak. Beta karoten yang merupakan karotenoid larut dengan baik pada pelarut nonpolar. Kepolaran n-heksan mendekati kepolaran karotenoid dari pada pelarut aseton dan etil asetat. Komponen karotenoid larut dalam pelarut non polar seperti n-heksan dan petroleum eter sedangkan kelompok xantofil larut dalam pelarut polar seperti alcohol (Wahyuni dan Wijarnoko, 2015). 


\section{KESIMPULAN}

Efektivitas pelarut heksana dan petroleum eter yang terbaik dalam mengekstrak beta karoten pada buah kelapa sawit yaitu pencampuran pelarut heksana $125 \mathrm{ml}$ : petroleum eter $375 \mathrm{ml}$ menghasilkan total padatan $94,94 \%$ dan total kandungan beta karoten 0,71 ppm.

\section{DAFTAR PUSTAKA}

Badan Pusat Statistik, 2015. Produksi Buah Sawit Indonesia.

Baennita, B. L., 2008 Karakterisasi Dan Furifikasi Antosianin Pada Buah Duwet (syzygium cumini). Skripsi, Fakultas Teknologi Pertanian. Institute Pertanian Bogor, Bogor.

Bonnie, T. Y. P., \& Choo, Y. M., 1999. Oxidation and Thermal Degradation of Carotenoids. J. Of Palm oil Research, I, 62-78.

Choo YM, Yapa SC, Ooi CK, Ma AN, Goh SH, Ong ASH. 1996. Recovered oil From Palm-Pressed Fiber: A Good Source Of Natural Carotenoids, Vitamin E, and Sterols. JAOCS, J Am Oil Chem Soc. 73(5):599-602. doi: $10.1007 / \mathrm{BF} 02518114$.

Fauzi, 2008. Kelapa Sawit, Budidaya, Pemanfaatan Hasil dan Limbah Analisa, Usaha dan Pemasaran, Edisi Revisi, Penebar Swadaya. Jakarta.

Gusti DR. 2012. Studi Pengaruh Kerusakan Beta-karoten dalam Pelarut Heksana, Aseton dan Metanol serta Tanpa Pelarut Dalam Udara Terbuka. Jurnal Penelitian Universitas Jambi Seri Sains., Vol 14 (2) : 25-28.

Kiswandono AA, 2011.Skrining Senyawa Kimia Dan Pengaruh Metode Maserasi Dan Refluks Pada Biji Kelor (Moringa oleifera, Lamk) Terhadap Rendemen Ekstrak Yang Dihasilkan. Jurnal Sains Natural Universitas Nusa Bangsa Vol. 1, No. 2, $126-134$.

Lung JKS, Destiani PD. 2018. Uji Aktivitas Antioksidan Vitamin A, C, E dengan Metode DPPH. Farmaka. 15(1):53-62. doi:https://doi.org/10.24198/jf.v15i1.12805.g5844.

Purnamasari N, MAM Andriani, Kawiji. 2013. Pengaruh Jenis Pelarut dan Variasi Suhu Pengering Spray Dryer terhadap Kadar Karotenoid Kapang Oncom Merah (Neurospora sp.). Jurnal Teknosains Pangan. Vol 2 (1) : 107-114.

Raharjo, 2004. Kerusakan Osidatif Pada Makanan. Pusat Studi Pangan dan Gizi, Universitas Gajah Mada, Yogyakarta.

Rahmawan, 2011. Prinsip Dasar Pengeringan. Jurusan Teknologi Industri Pertanian Bogor. IPB. Bogor.

Supardan MD, Asnawi TM, Putri Y \& Wahyuni S. 2009. Metode Ekstraksi Pelarut Berbantuan Ultrasonik Untuk Recovery Minyak dari Limbah Cair Pabrik Kelapa Sawit. AGRITECH Vol. 31. Hal. 368.

Tamara A dan Purwanto WW. 2013. Kesetimbangan Cair-Cair Untuk Esktraksi Betakaroten Dari Minyak Sawit Kasar Dengan Pelarut Isopropanol. Fakultas Teknik.

Wahyuni DT dan Widjarnoko SB. 2015. Pengaruh Jenis Pelarut Dan Lama Ekstraksi Terhadap Ekstrak Karotenoid Labu Kuning Dengan Metode Gelombang Ultrasonik. Jurnal Pangan dan Agroindustri Vol. 3 No 2 p.390-401. 
Yulianti, 2013. Ekstraksi $\beta$-etakaroten Dari Wortel Dengan Pelarut Heksana Dan Petroleum Eter. Tesis. Program Pascasarjana. Universitas Hasanuddin. Makasar.

Yulianti, Amran Laga, dan Meta Mahendradatta. 2017. Ekstraksi Beta Karoten Dari Wortel Dengan Pelarut Heksana Dan Petroleum Eter. Jurnal Bertani. Volume 12 No. 1 Hal : 48-58. 